\title{
Carbonate dissolution without acid: the role of endolithic cyanobacteria and hydrolysis in rock weathering
}

\author{
HENRY J. SUN ${ }^{1}$
}

${ }^{1}$ Desert Research Institute, 755 E. Flamingo Rd., Las Vegas, Nevada 89119, henry.sun@dri.edu

\section{Results}

Marble monuments at the Forbidden City Mausoleum in Beijing, China, show signs of rapid surface disintegration (Figure 1). The weathering is not caused by air pollution. In northern China, owing to carbonate-rich aeolian dust from the Mongolian desert, air pollution does not produce acid rain. Rather, the culprits are endolithic cyanobacteria who entered the monuments via cracks, joints, or damaged corners. Once established, the colonies spread underneath the protective stone surface by actively dissolving carbonate. When the rock is wet, the photosynthetizing organisms rapidly remove $\mathrm{CO}_{2}$ and bicarbonate, resulting in unsaturated porewater that dissolves surrounding minerals by hydrolysis. Hence, dissolution follows crystallographic planes and twinning, and DNA analysis revealed the presence of eu-endolithic or calcium-boring species.

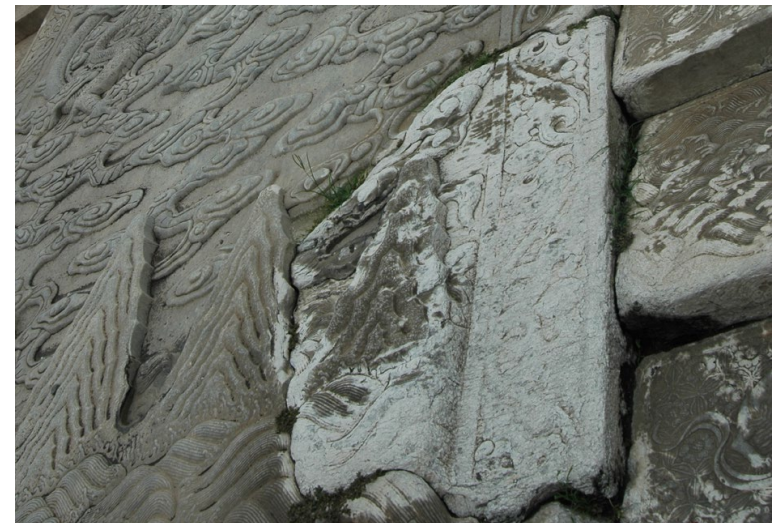

Figure 1. Localized marble decay in the courtyard of the Forbidden City, Beijing, China.

\section{Implications}

Similar deteriorations occur on ancient stone monuments elsewhere in the world. Traditionally, these damages are assumed to be related to air pollution. In light of this study, the wisdom of the assumption should be questioned. This is not to say that acid rain does not dissolve carbonate. Damaged stones are not necessarily caused by acid rain. 